\title{
AIKUISKOULUTUKSEN TARPEET JA TAVOITTEET
}

Jo aiemmin Kasvatus lehdessä $3 / 1990$ määrällisen koulutussuunnittelun arviointiamme kritikoinut opetusministeriön suunnittelija Olli Poropudas kirjoitti Aikuiskasvatuksen numerossa 3/1990 yhteisistä asioistamme vieläkin niin innostavasti, ettei keskustelua ole syytä katkaista.

Koulutussuunnittelun neuvottelukuntaa edustavaa Poropudasta kiinnosti tällä kertaa näkemyksemme aikuiskoulutuksen kehittämisestä, mitoittamisesta ja mahdollisuuksista. Eniten hän näytti olleen harmissaan siitä, ettemme olleet riittävästi noteeranneet Väestön koulutus 2000 -mietinnön aikuiskoulutuksen kannalta ainutlaatuista historiallista arvoa. Mietinnössä on näet ensi kertaa esitetty aikuiskoulutukselle määrälliset, myös työvoimatarpeet sisältävät tavoitteet.

Emme mekään muuta väittäneet. Mutta keskityimme erityisesti määrällisen koulutussuunnittelun arviointiin, ja siksi käsittelimme aikuiskoulutusta vain joiltain osin. Eikä sen nyt niin vaarallista pitäisi olla, jos pelkän kehumisen sijasta löydämme mietinnöstä muutamia heikkouksiakin.

\section{Aikuisten erilaiset tarpeet}

Nuoriin verrattuna aikuisten koulutukseen osallistuminen riippuu ensisijaisesti heidän tarpeitaan ja preferenssejään vastaavan koulutuksen saatavuudesta. Työvoimamenetelmä tuskin toimii tässä suunnittelussa yhtään sen paremmin kuin nuorisokoulutuksessakaan.

Poropudas kysyy, lisääntyisikö aikuisten vapaus, jos valikointi koulutukseen siirtyisi kouluilta työpaikoille. Hän viittaa ehdotuksiimme yksinkertaisen koulutus-työ -kytkennän purkamisesta ja informaalin, oppisopimustyyppisen "'koulutuksen"' lisäämisestä. Samat valikoitumisen ja kasaantumisen mekanismit vaikuttavat tietysti niin aikuis- kuin nuorisokoulutuksessa. Niitä ei voida koulutussuunnittelulla poistaa eikä juuri lieventääkään, koska ongelmat ovat työmarkkinoilla ja työelämässä. Nuorten mahdollisuudet ja ehkä tasa-arvoisuuskin sensijaan saattaisi lisääntyä, jos aivan liian pitkäksi paisunutta yhtäjaksoista koulujärjestelmäkoulutusta voitaisiin purkaa sekä tarjota vaihtoehtoisia koulutusmalleja ja jatkuvan koulutuksen idean implikoimia vaihtoehtoisia työmalleja.
Kummastelemme edelleen Poropudaksen ajatuksia suunnittelun prosessiluonteen ja konservatiivisuuden autuudesta. Jos näkemys aikuiskoulutukseenkin on, että " aika näyttää kuinka suureksi aikuiskoulutus loppujen lopuksi muodostuu", Ei "suunnittelu" tainne suunnittelijoistakaan kovin innostavalta tuntua. Tulee mieleen jopa suunnittelua suunnittelevien suunnittelijoiden tarve.

\section{Tarpeista tavoitteisiin}

Toinen neuvottelukunnan uraa uurtavana esittämä innovaatio on tarpeiden ja tavoitteiden erottaminen toisistaan. Väestön koulutustarpeet ovat paitsi erilaisia yleensä myös ristiriitaisia. Koulutustavoitteet puolestaan ovat sopimuksenvaraisia. Tavoitteet pyritään asettamaan siten, että erilaiset tarpeet tulevat mahdollisimman hyvin tyydytetyiksi.

Erottelu on asiallinen, muttei erityisen uusi. Tarpeet ja tavoitteet on käsitetty eri asioiksi ainakin koulutusrakennekomitean mietinnöstä lähtien. Uutta on ehkä se, miten ja millaisia tavoitteita asetetaan. 1970-luvullahan vasta rakennettiin koko ikäluokan ammattikoulutusta, ja tavoitteiden asettelussa vaikutti se, ettei kaikkien laskennallisia tarpeita voitu resurssisyistäkään edes ajatella yhtä aikaa tyydytettävän.

Poropudas päättelee: jos nuorisokoulutus suunnitellaan työvoimamenetelmällä, pitää näin tehdä aikuiskoulutuksessakin. ' 'Kysyntämenetelmän soveltamisen tuloksena olisi, että paitsi aikuiset myös nuoret joutuisivat kärsimään aikuisten valintojen seurauksista, työttömyydestä, sijoittumisesta koulutusta vastaamattomiin työpaikkoihin jne".

Työvoima- ja koulutuskysyntämenetelmän turha vastakkainasettelu perustuu ajatukseen, jonka mukaan työvoimamenetelmä johtaa väistämättä koulutuspaikkojen tarjoamiseen vastoin väestön koulutuspreferenssejä, kysyntämenetelmän käyttö taas työelämän tarpeita vastaamattomaan koulutusrakenteeseen. Yhteiskunnan kokonaisedun mukaista on valita työvoimamenetelmä, jotta ei vaarannettaisi yhteiskunnan tuotantojärjestelmää.

Poropudaksen mukaan on olemassa yhtäältä koulutustarjonnan niukkuuden ongelma ja toi- 
saalta työvoiman tarpeen ongelma: 'Jos lisäämme koulutuspaikkoja, ratkaisemme ensimmäistä ristiriitaa. Jos kohdennamme sen niille aloille, joilla on tai arvioidaan tulevaisuudessa olevan työvoiman tarvetta, ratkaisemme toista ristiriitaa. Jos teemme sekä että, saamme vastauksen molempiin ongelmiin".

Tiettyjä koulutuskapasiteettia täytyy luonnollisesti ylläpitää. Mutta aivan oma ongelmansa on, mistä ja miten saadaan opiskelijat, varsinkin jos on kyse vähemmän suosituista koulutusaloista. Ikäluokkien pienentyessä tämä ongelma tulee kärjistymään. Koska ylitarjontaa ei juuri ole, vähemmän arvostetut aloituspaikat jäävät yhä todennäköisemmin tyhjiksi.

Koulutusjärjestelmän strategisen suunnittelun kannalta puolestaan tuntuisi järkevältä ja mahdolliselta vastata joidenkin suosituimpien alojen kovaan kysyntään koulutuspaikkoja lisäämällä. Tämä voisi olla myös taloudellisesti järkevää, sillä oppilasvirtojen kasaantuminen aiheuttaa huomattavia välittömiä ja välillisiä kustannuksia. Ja onhan näin tehty ennenkin.

\section{Ennustettavuus vaikeutuu entisestään}

Poropudaksen mukaan siis myös aikuisten ammatillinen koulutus tulee suunnitella työvoimamenetelmää käyttäen. Olemme monien muiden kommentaattorien tavoin painottaneet vaihtoehtoisten ennusteiden tärkeyttä silloin, kun määrällinen koulutussuunnittelu käyttää lähes yksinomaan hyödykseen työvoimamenetelmää. Tämä on tärkeää ennen kaikkea aikuisten ammatillisen koulutuksen suuntaamisessa.

Vaihtoehtojen käyttö pakottaa tarkastelemaan " vahvoja" ammattiryhmiä, joiden kasvu voi olla hyvin voimakasta, ja "'heikkoja" ammattiryhmiä, jotka ovat alttiita rakennemuutoksille ja työttömyydelle.

Siitä olemme yhtä mieltä Poropudaksen kanssa, että vaihtoehtojen tarkastelu ei saa olla itseisarvo, eiväthän ne yhtään vähennä ennustamiseen liittyvää epävarmuutta. Katsomme kuitenkin, että vaihtoehtojen esittämisellä saadaan eri ammattiryhmistä sellaista tärkeää tietoa, jolla koulutussuunnittelu pystyy varautumaan yllättäviinkin tilanteisiin.

Olemme tietoisia siitäkin, että poliittiset päättäjät edellyttävät tuekseen selkeitä ennusteita eivätkä suunnittelijat tässä välikädessä voi heittäytyä pelkästään vaihtoehtojen pohtijoiksi. Näemme senkin, että " vaihtoehtoisia koulutuspaikkoja" on hankala rakentaa ja että rakennettu ylikapasiteetti on OPM:n ja VM:n näkökulmasta kalliimpaa kuin "'rakentamaton alikapasiteetti". Tässä on nähdäksemme joustavampien koulutusjärjestelyjen kehittely maassamme vasta alkutekijöissään. Vaihtoehtojen esittely myös jäntevöittäisi koulutuspoliittista keskustelua.

Nyt saa kuitenkin sellaisen vaikutelman, että vaikka vaihtoehdot hyvinkin ovat suunnittelijoiden tiedossa, ei niihin varauduta muutoin kuin tekemällä ennusteen tarkiste tai rohkeimmillaan laaditaan tyystin uusi ennuste.

\section{Sakari Ahola, Arto Kankaanpää,

